Yuslena Sari, Irfan Prasetia — Sistem Informasi Manajemen Berbasis UML (Studi Kasus Pemeliharaan Toilet Pada Kampus Fakultas Teknik Universitas Lambung Mangkurat)

\title{
SISTEM INFORMASI MANAJEMEN BERBASIS UML (STUDI KASUS PEMELIHARAAN TOILET PADA KAMPUS FAKULTAS TEKNIK UNIVERSITAS LAMBUNG MANGKURAT)
}

\author{
Yuslena Sari ${ }^{1)}$ dan Irfan Prasetia ${ }^{2)}$ \\ ${ }^{1}$ Department of Civil Engineering, Lambung Mangkurat University \\ ${ }^{2}$ Department of Information Engineering, Lambung Mangkurat University \\ e-mail: yuzlena@gmail.com ${ }^{1)}$, iprasetia@,unlam.ac.id ${ }^{2)}$
}

\begin{abstract}
ABSTRAK
Makalah ini menyajikan konsep sistem database pada sebuh sistem perangkat lunak komputer. Persyaratan analisis dan desain adalah masalah serius dalam pengembangan sebuah sistem yang berjalan secara manual kedalam sebuah sistem perangkat lunak computer yang serba otomatis. Untuk menjembatani kedua sistem tersebut (manual dan otomatis), bahasa pemodelan Unified Modeling Language (UML) kini diterima sebagai standar de facto untuk desain dan spesifikasi sistem yang berorientasi objek. Pada penelitian ini, Bahasa pemodelan ULM digunakan untuk merancang Sistem Informasi Manajemen (SIM) Pemeliharaan toilet pada Kampus Fakultas Teknik Universitas Lambung Mangkurat menggunakan database Acces 2013. Dari sistem tersebut, maka pimpinan yang berperan sebagai admin, dapat langsung mengetahui kerusakan atau keperluan perbaikan secara real time setiap hari. Informasi tersebut akan sangat membantu pimpinan dalam pengambilan keputusan terkait monitoring, pemeliharan dan perbaikan toilet kampus Fakultas Teknik Universitas Lambung Mangkurat. Hasil akhir yang diharapkan adalah agar toilet kampus Fakultas Teknik Universitas Lambung Mangkurat selalu terjaga kebersihan dan keandalannya.
\end{abstract}

Katakunci: UML; SIM; Pemeliharaan Toilet

\section{ABSTRACT}

This paper presents concept of a database system on a computer software systems. Requirements in analysis and design are a serious problem in developing a manual system into a computer software system that is fully automated. To link the two systems (manual and automatic), a modeling language Unified Modeling Language (UML) is now accepted as the de facto standard for the design and specification of object-oriented systems. In this study, ULM modeling language used to design a management information system (MIS) of Toilet Maintenance on the Faculty of Engineering, Lambung Mangkurat University using Access 2013. From this system, dean as admin of the system, can immediately know the damage or the need of maintenance in real time every day. Such information would greatly assist the management on making decision related to monitoring, maintenance and repair of toilet in the Faculty of Engineering, Lambung Mangkurat University. The final results is to keep the cleanliness and reliability of toilet in the Faculty of Engineering, Lambung Mangkurat University.

Keywords: UML; MIS; Toilet Maintenance

\section{PENDAhUluan}

Akhir - akhir ini, analisis kebutuhan dan spesifikasi desain rekayasa perangkat lunak merupakan tugas yang menantang karena merupakan hal yang sulit untuk mentransformasikan masalah dunia nyata diverifikasi ke dalam model komputer (N. H. Ali, 2007). Langkah pertama dalam mengembangkan metodologi desain berorientasi obyek untuk perangkat lunak serta untuk sistem database adalah penggunaan UML (Unified Modeling Language) sebagai notasi standar untuk desain dan arsitektur pemodelan sistem, ada banyak pilihan untuk menjadikan sistem apliaksi computer dan sistem database tersebut menjadi handal, fleksibel dan efisien. Pilihannya adalah Objek Oriented, Object Relational hybrids, pure Relational dan custom solutions based on open or proprietary file formats. UML dianggap sebagai industri bahasa standar pemodelan dengan notasi grafis yang kaya, comprehensive set diagram dan elemen. Hal ini digunakan untuk menentukan, memvisualisasikan, memodifikasi, membangun dan mendokumentasikan artefak sistem intensif software berorientasi objek yang dikembangkan.

Makalah ini menyajikan UML dari Sistem Informasi Manajemen Pemeliharaan toilet kampus Fakultas Teknik Universitas Lambung Mangkurat. Ringkasan sistem database, konsep UML dan diagram terkait akan dibahas dalam makalah ini. Diagram UML yang berbeda untuk aplikasi database juga bisa diintegrasikan ke proses pengembangan perangkat lunak yang berbeda.

\section{II.TINJAUAN PUSTAKA}


A. Sistem Manajemen Basis Data

Di dalam dunia teknologi informasi, data biasanya disimpan dengan sistematika yang terdiri dari elemen data (data field), rekaman (record), dan berkas (file). Elemen data dapat berupa nama, nomor pegawai, alamat seseorang pada catatan identitas karyawan perusahaan. Elemen data berada pada tingkat terendah hierarki data. Beberapa elemen data tersebut kemudian berkumpul dan mem-bentuk rekaman. Rekaman (record) adalah kumpulan elemen data yang merujuk pada satu objek data atau kegiatan tertentu. Misalkan file tentang data pegawai maka sebuah rekaman akan menunjukkan data tentang seorang karyawan tertentu. Field-field data yang ada akan menjelaskan atribut-atribut tentang karyawan tersebut, misalnya nama, alamat, tanggal lahir dan lain sehagainya. Kemudian, rekaman-rekaman itu dikumpulkan. Kumpulan rekaman-rekaman yang disimpan itu dinamakan file (berkas). Misalnya, gabungan dari seluruh catatan rekaman karyawan perusahaan disimpan dalam satu file yang dinamakan File Karyawan. Biasanya file-file tersebut saling berinterkoneksi dalam sebuah kumpulan dan membentuk satu sistem data, yang kemudian disebut Basis Data (database). Gambar sistematika penyimpanan data dapat dilihat pada Gambar 2.1 berikut.

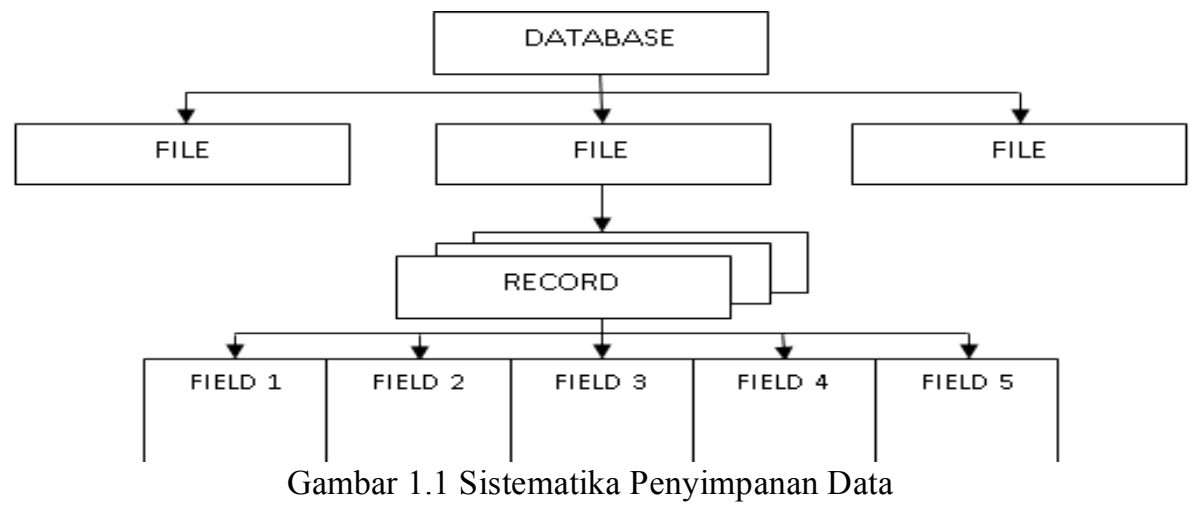

(Nugroho, 2008)

Proses untuk mengelola data-data perusahaan disebut manajemen data. Manajemen data merupakan bagian dari manajemen sumber daya informasi. Tujuannya adalah memastikan sumber daya data perusahaan tetap akurat, mutakhir, aman dan tersedia bagi pemakai. Sebelum ada sistem basis data, data-data organisasi/perusahaan disimpan dalam file-file yang terpisah satu dengan yang lain. Padahal file-file tersebut banyak berisi data yang sama, misalnya data nama pegawai sering terdapat di berbagai file, baik file kepegawaian, file penjualan, file keuangan dan lain sebagainya. Oleh karena file-file tersebut tidak terorganisasi maka muncul kelemahan-kelemahan. Adapun kelemahan tersebut antara lain sebagai berikut:

1. Pengulangan data (duplikasi)

2. Ketidakseragaman perekaman data

3. Ketidakkonsistenan data

Kelemahan tersebut mendorong para ahli teknologi informasi untuk mencari solusi yang mengarahkan mereka pada pengorganisasian data yang sistematis. Penyusunan organisasi data secara sistematis ini menghasilkan sebuah sistem teknologi basis data. Dengan sistem basis data, berbagai file tersebut diorganisasi menjadi satu kesatuan yang saling berhubungan sehingga merupakan satu kesatuan yang terintegrasi. Secara fisik file-file tersebut tetap saling terpisah, bahkan barangkali saling berjauhan letaknya, tetapi secara logika mereka semua merupakan satu kesatuan. Dengan demikian, basis data merupakan suatu kumpulan data komputer yang terintegrasi, diatur dan disimpan sedemikian rupa sehingga memudahkan pengolahannya. Jenis pengolahan data umumnya ada 3 (tiga) yaitu Create (tambah data), Update (ubah data) dan Delete (menghapus data).

B. UML

UML memiliki berbagai manfaat untuk pemodelan sistem. UML merupakan bahasa semi-formal di mana masing-masing unsur bahasa sangat ditentukan (Podeswa, 2009). UML bersifat ringkas dan mudah dipahami (Raymond, 2004). UML memiliki konsep yang sederhana, mudah dan berupa notasi. UML adalah bahasa yang komprehensif dan dapat menjelaskan semua aspek penting dari sebuah sistem. Meskipun UML bukan bahasa yang formal tetapi memiliki daya ekspresif yang dapat menangani sistem yang besar dan kompleks (Sengupta \& Bhattacharya, 2008). UML terbukti memberi hasil terbaik dari pemodelan sistem yang menggunakan object oriented. UML juga telah menjadi standart de facto untuk modeling dari sistem yang menggunakan teknologi object oriented (Shi, 2012) 
Yuslena Sari, Irfan Prasetia — Sistem Informasi Manajemen Berbasis UML (Studi Kasus Pemeliharaan Toilet Pada Kampus Fakultas Teknik Universitas Lambung Mangkurat)

\section{ANALISA DESAIN SISTEM}

\section{A. Use case Diagam}

Use case diagram adalah salah satu diagram UML yang digunakan untuk mewakili fungsi dari sistem. Use case diagram menunjukkan fungsi - fungsi dari user - user yang berkomunikasi dengan sistem. Notasi notasi use case diagram seperti aktor, communication association dan system atau subsystem boundary. Use case diagram menyediakan interaksi antara peran yang dikenal sebagai aktor dan sistem untuk mencapai suatu tujuan tertentu. Manusia atau sistem eksternal, keduanya diasumsikan sebagai aktor dalam definisi dari use case diagram. Use case diagram mendefinisikan kefungsian sistem dari perspektif pengguna dan digunakan untuk mendokumentasikan lingkup sistem. Biasanya, penggunaan use case digunakan pada tingkat yang lebih tinggi dalam rekayasa sistem dibandingkan dengan penggunaannya dalam rekayasa perangkat lunak. Adapun use case pada Sistem Informasi Manajemen Pemeliharaan toilet kampus Fakultas Teknik Universitas Lambung Mangkurat dapat dilihat pada Gambar 3.1 dan 3.2.

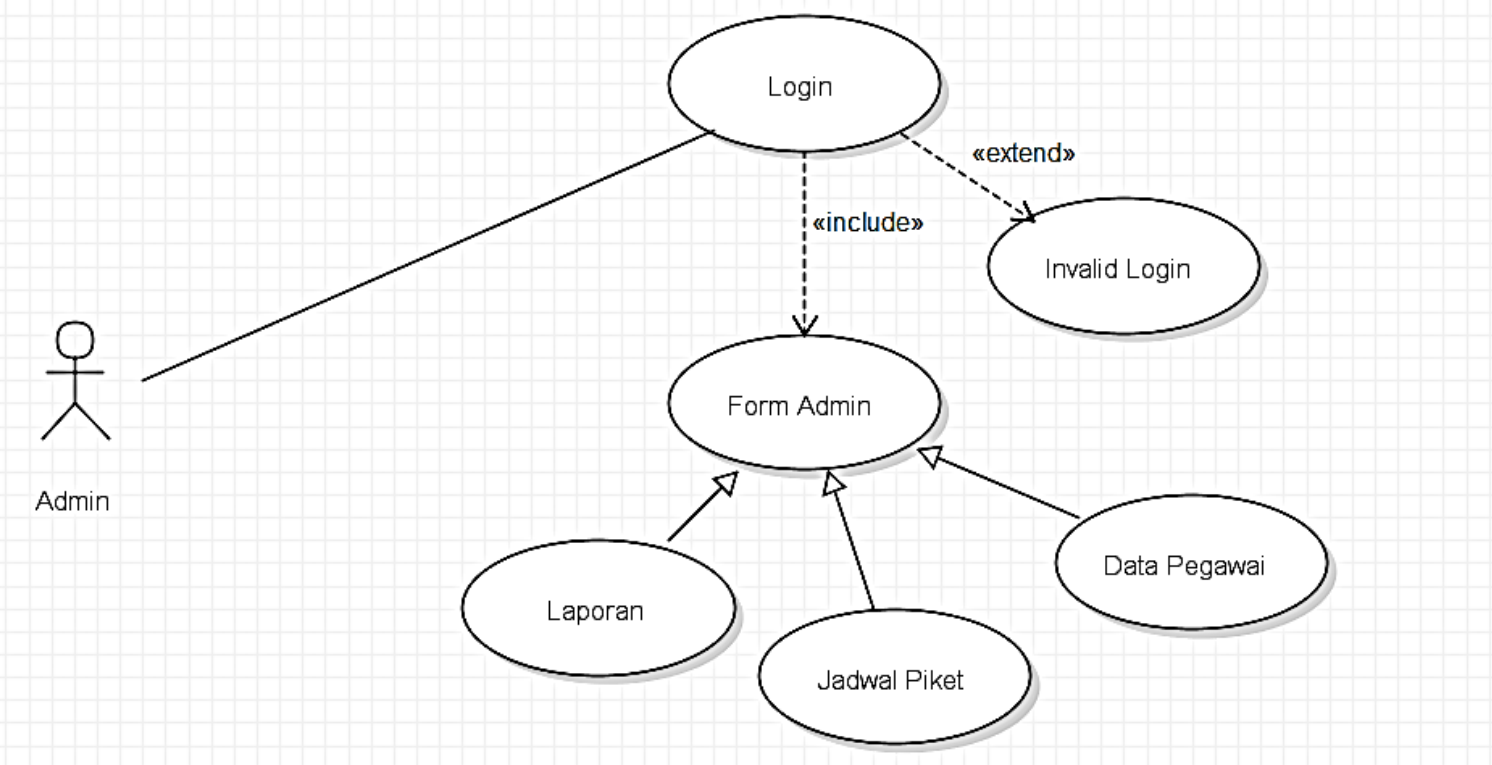

Gambar 3.1 Use case Diagram admin

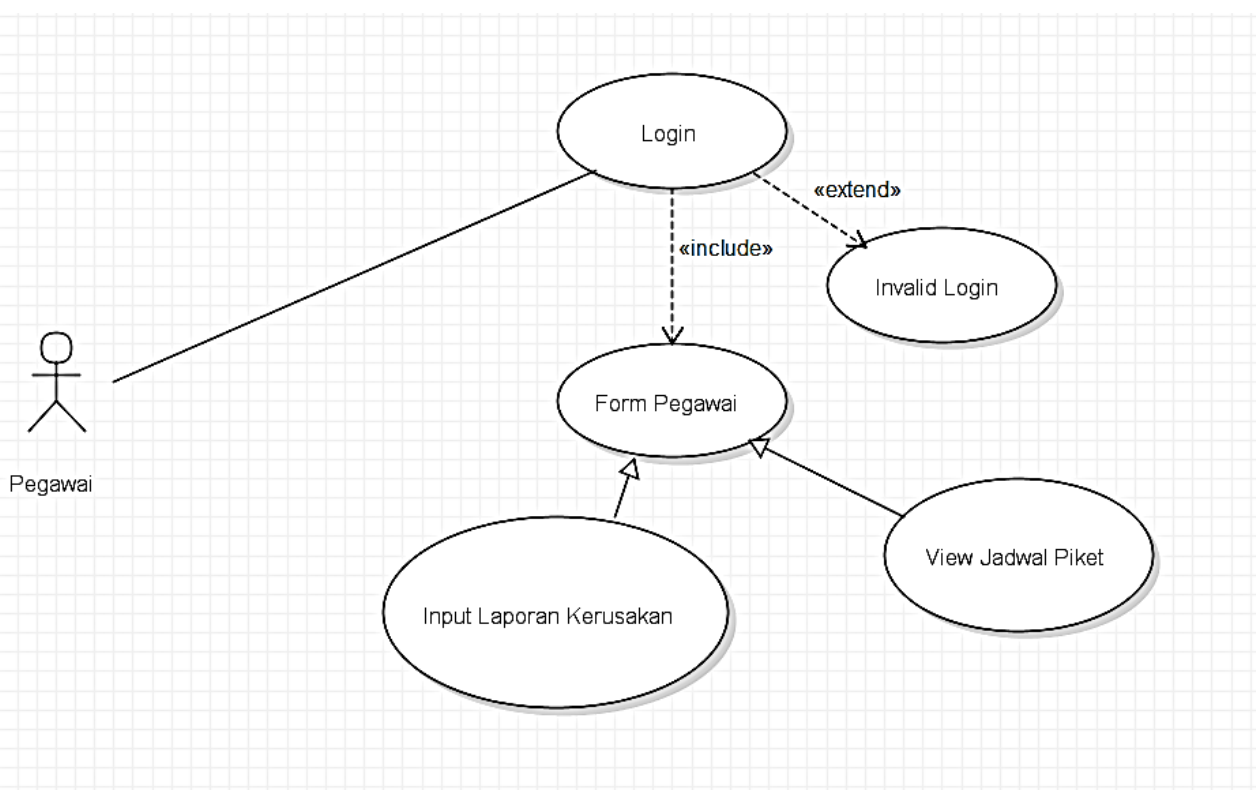

Gambar 3.2 Diagram Usecase Pegawai

Aktor yang ada pada sistem ini ada dua yaitu admin dan user. Admin adalah orang yang bertugas dan memiliki hak akses untuk melakukan operasi pengelolaan data pegawai, data jadwal piket dan data laporan kerusakan. 


\section{B. Class Diagram}

Class diagram adalah struktur diagram yang digunakan untuk menunjukkan kelas dan hubungan kelas tersebut satu sama lain. Diagram kelas meliputi notasi seperti kelas, atribut, operasi dan asosiasi (Bennett, 2011). Kelas di diagram UML digunakan untuk menangkap informasi tentang sistem yang akan dikembangkan. Sebuah kelas adalah artefak di diagram UML yang dapat membuat sejumlah objek untuk berbagi atribut, operasi, hubungan antara objek-objek, dan beberapa semantik lainnya pada diagram. Sebuah kelas dalam UML terdiri dari tiga bagian yaitu nama kelas, atribut dan operasi. Class diagram memiliki empat jenis relasi yaitu association, generalisasi, agregasi dan komposisi antar kelas. Assosiation digunakan untuk menangkap hubungan antara objek-objek dari kelas. Dalam hubungan ini adalah ditentukan bagaimana objek saling terhubung satu sama lain. Suatu relasi adalah link yang berkaitan satu set ke yang lain dengan informasi yang diperlukan untuk berhubungan. Ada berbagai jenis hubungan asosiasi, yaitu, banyak ke banyak, banyak ke satu, satu ke banyak dan 1-1. Misalnya dalam hubungan jadwal piket dengan pegawai pada Sistem Informasi Manajemen Pemeliharaan toilet kampus, sebagai salah satu pegawai guru dapat jadwal piket lebih dari satu itu sebabnya kita dapat menggambarkan hubungan ini satu ke banyak.

Gambar 3.3 menunjukkan class diagram Sistem Informasi Manajemen Pemeliharaan toilet kampus Fakultas Teknik Universitas Lambung Mangkurat:

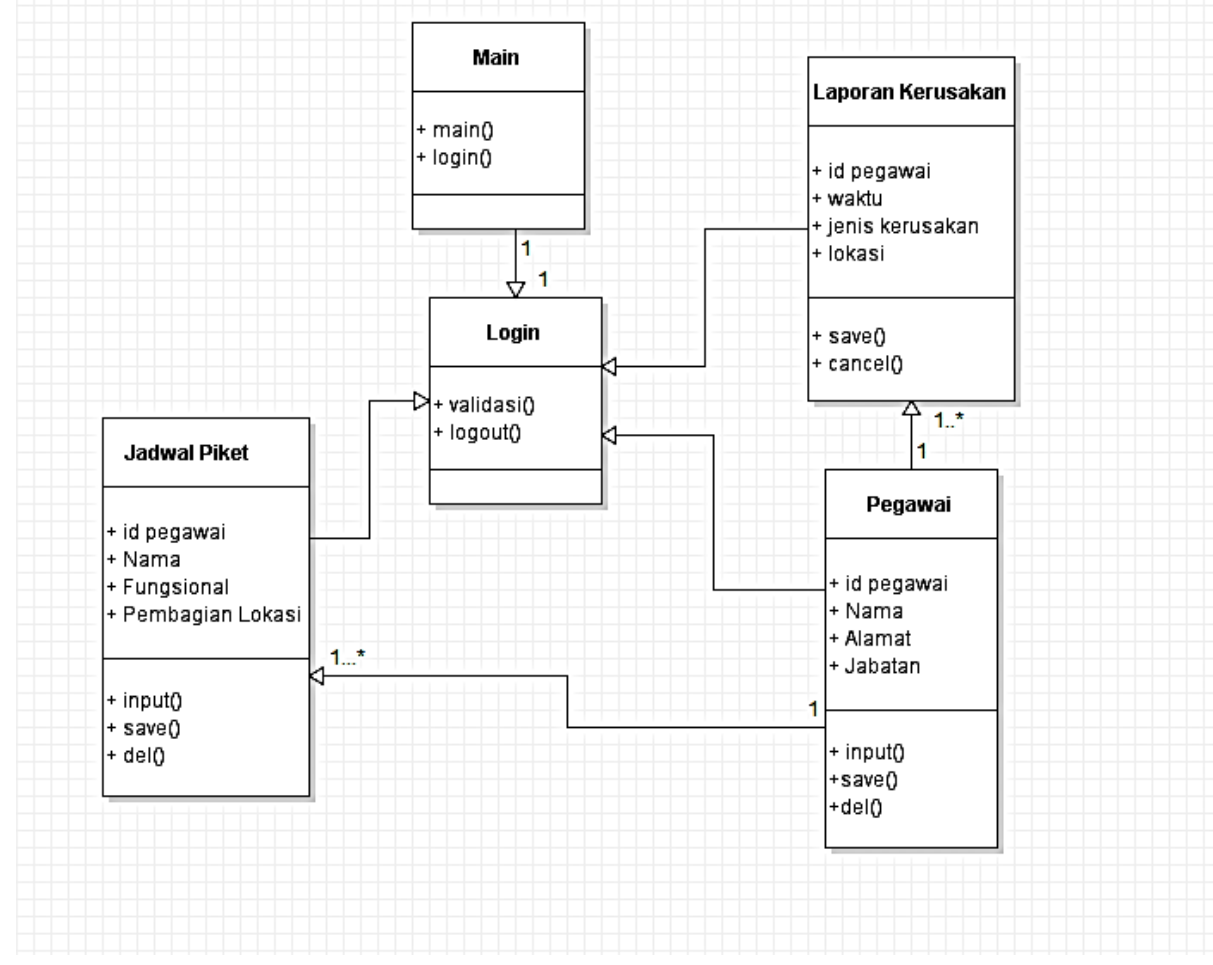

Gambar 3.3. Class Digram Sistem

Main merupakan kelas main yang juga merangkap sebagai kelas yang menangani tampilan. Login merupakan kelas proses yang diambil dari pendefinisian usecase login. Pegawai merupakan kelas data yang digunakan untuk membungkus hasil inputan data pegawai. Jadwal piket yaitu kelas data dari hasilproses inputan jadwal piket. Laporan Kerusakan adalah kelas proses yang diambil dari form laporan kerusakan oleh pegawai.

\section{Database Sistem}

Tujuan dari database sistem adalah mengurangi redundansi data, mengintegrasikan data dan memungkinkan berbagi informasi di antara berbagai kelompok dalam organisasi. Database sistem adalah istilah yang biasanya digunakan untuk merangkum konstruksi dari model data, sistem manajemen database (Database Manajemen System atau DBMS) dan database. Sebuah DBMS adalah serangkaian perangkat lunak komputer yang menyediakan interface antara pengguna dan database atau database dengan database. Sebuah DBMS adalah shell yang mengelilingi database atau serangkaian database dan melalui mana semua interaksi berlangsung dengan database.

Database Sistem Informasi Manajemen Pemeliharaan toilet kampus Fakultas Teknik Universitas Lambung Mangkurat. 
Yuslena Sari, Irfan Prasetia — Sistem Informasi Manajemen Berbasis UML (Studi Kasus Pemeliharaan Toilet Pada Kampus Fakultas Teknik Universitas Lambung Mangkurat)

Database yang terbentuk dalam Sistem Informasi Manajemen Pemeliharaan toilet kampus Fakultas Teknik Universitas Lambung Mangkurat:
a. Nama File
Media
: Data Pegawai
Isi
: Harddisk
Organisasi
: Data Pegawai
Primary Key
: Index Sequental
Panjang Record
:Id_pegawai
Struktur
: 75 Byte

\begin{tabular}{|l|l|l|l|l|l|}
\hline No & Nama Field & \multicolumn{1}{|c|}{ Jenis } & Lebar & Desimal & \multicolumn{1}{|c|}{ Keterangan } \\
\hline 1 & Id pegawai & Varchar & 5 & & Kode Pegawai \\
\hline 2 & Nama & Varchar & 25 & & Nama Pegawai \\
\hline 3 & Alamat & Varchar & 30 & & Alamat Pegawai \\
\hline 4 & Jabatan & Varchar & 15 & & Jabatan \\
\hline
\end{tabular}

b. Nama File

Media

Isi

: Jadwal Piket

Organisasi

: Harddisk

Primary Key

: Data Jadwal Piket

Panjang Record

: Index Sequental

:Id_pegawai

: 90 Byte

Struktur

\begin{tabular}{|l|l|l|l|l|l|}
\hline No & \multicolumn{1}{|c|}{ Nama Field } & \multicolumn{1}{|c|}{ Jenis } & Lebar & Desimal & \multicolumn{1}{|c|}{ Keterangan } \\
\hline 1 & Id_pegawai & Varchar & 5 & & Kode Pegawai \\
\hline 2 & Nama & Varchar & 25 & & Nama Pegawai \\
\hline 3 & Fungsional & Varchar & 30 & & Fungsional Pegawai \\
\hline 4 & $\begin{array}{l}\text { Pembagian } \\
\text { Lokasi }\end{array}$ & Varchar & 30 & & Lokasi \\
\hline
\end{tabular}

c. Nama File

Media

Isi

: Data Laporan Kerusakan

Organisasi

: Harddisk

Primary Key

: Data Kerusakan

Panjang Record

: Index Sequental

Struktur

: Id_pegawai

:75 Byte

\begin{tabular}{|l|l|l|l|l|l|}
\hline No & \multicolumn{1}{|c|}{ Nama Field } & Jenis & Lebar & Desimal & \multicolumn{1}{|c|}{ Keterangan } \\
\hline 1 & Id_pegawai & Varchar & 5 & & Kode Pegawai \\
\hline 2 & Waktu & Varchar & 25 & & Nama Pegawai \\
\hline 3 & Laporan & Varchar & 30 & & Alamat Pegawai \\
\hline 4 & Lokasi & Varchar & 15 & & Lokasi kerusakan \\
\hline
\end{tabular}

\section{KESIMPULAN}

UML adalah alat untuk menentukan sistem perangkat lunak yang mencakup standar diagram untuk mendefinisikan, menggambarkan dan visual map atau memodelkan desain dan struktur sistem perangkat lunak. Makalah ini diuraikan penggunaan UML sebagai notasi standar dunia dalam mengembangkan metodologi desain berorientasi objek untuk aplikasi komputer dan sistem database.

Peran use case diagram pada tahap analisis dari pemodelan dan perancangan sistem memberikan manfaat yang jelas di bagian pemodelan sistem. Seperti kita ketahui kompleksitas adalah salah satu kesulitan utama dalam analisis sistem dan desain. Manfaat penting dari menggunakan use case adalah membantu mengelola kompleksitas sistem. Hal ini karena penekanan pada penggunaan tertentu dengan memulai dari sudut pandang yang sangat sederhana dengan berfokus pada pengguna sistem. Use case memberikan kerangka 
dasar dari analisis kebutuhan dan penggunaan use case juga memfasilitasi untuk desainer untuk menentukan dan mencapai tujuan akhir dalam pengembangan sistem.

Class diagram di UML adalah blok yang paling penting untuk pemodelan dan desain sistem berorientasi objek. Atribut dalam class diagram merupakan model yang sangat baik dan praktis karena dengan cara ini dapat menjamin perlindungan keamanan data jika diperlukan. Multiplisitas dalam hubungan antara class diagram merupakan konsep penting yang diperlukan dalam banyak aplikasi.

\section{DAFTAR PUSTAKA}

\section{BIBLIOGRAPHY}

[1]. Z. N. H. Ali, "A Design of an Assessment System for UML Class Diagram," International Conference on Computational Science and Applications, pp. 539-546, 2007.

[2]. H. Podeswa, "UML for IT Business Analyst," 2nd Edition Course Technology, 2009.

[3]. T. B. Raymond, "Integrating Formal Methods by Unifying Abstractions," Springer, vol. 2999, pp. 441-460, 2004.

[4]. S. Sengupta and S. Bhattacharya, "Formalization of UML Diagrams and Consistency Verification: A Z Notation Based Approach," in Proceedings of India Software Engineering Conference, Hyderabad, 2008.

[5]. Z. Shi, "Intelligent Target Fusion Recognition Based on Fuzzy Petri Nets," Information Technology Journal, vol. 11, pp. 500-503, 2012.

[6]. S. Bennett, Object-Oriented Systems Analysis and Design Using UML, 4th ed. New York: McGraw-Hill, 2011. 